\title{
Társadalmi-területi egyenlőtlenségek
}

\author{
Sociospatial disparities
}

\author{
FARAGÓ LÁSZLÓ
}

\begin{abstract}
FARAGÓ László: tudományos főmunkatárs, MTA Közgazdaság- és Regionális Tudományi Kutatóközpont, Regionális Kutatások Intézete; 7621 Pécs, Papnövelde u. 22.; egyetemi tanár, Széchenyi István Egyetem, Regionális Tudományi és Közpolitikai Tanszék; 9026 Győr, Egyetem tér 1.; farago@rkk.hu
\end{abstract}

László FARAGÓ: senior research fellow, Institute of Regional Studies, Centre for Economic and Regional Studies, Hungarian Academy of Sciences; Papnövelde u. 22., H-7621 Pécs, Hungary; professor, Department of Regional Science and Public Policy, Széchenyi István University; Egyetem tér 1., H-9026 Györ, Hungary; farago@rkk.hu

A rendelkezésemre álló szűk terjedelmi (műfaji) keretek között csak arra van mód, hogy tézisszerüen fogalmazzak meg néhány megállapítást, kiemeljek néhány sajátos (pl. társadalomkonstruktivista) aspektust, rávilágítsak néhány ismert jelenség másik oldalára.

A társadalmi-területi egyenlőtlenségek a társadalomtudományok, azon belül elsősorban a tértudományok (térfilozófia, társadalomföldrajz, regionális tudomány, regionális tanulmányok, térszociológia, településszociológia, urbanisztika stb.) vizsgálati területe.

\section{Mindig voltak és lesznek társadalmi-területi különbségek}

A téri, a területi különbségek (differenciák) léte (pl. a területi tőkében) és az egyenlőtlen fejlődés axióma. A tértudományok egyik alapállítása, hogy a fizikai különbözőség, a társadalmi egyenlőtlenség, a gazdasági egyensúlytalanság az általános (,természetes”) állapot. A fizikailag létező dolgok (pl. a természet tárgyai, a művi környezet) és a szellemi javak (pl. tudás) mindig különböznek legalább a területi-időbeni koordinátáikban és egyenetlen eloszlást mutatnak (pl. a földrajzi térben). Teljes kiegyenlítődés sohasem jön létre. Minden az egyenlőtlenségeken keresztül fejlődik, alakul. Az egyenlőtlen területi fejlődés nem egyszerűen a kapitalista termelési mód sajátja, mint azt a marxista politikai gazdaságtan gyakran sejteti, hanem a fejlődés strukturális kérdése és a téri lét

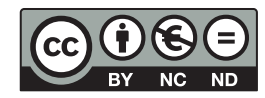


lényegéből ered. (A kapitalista piacorientált gondolkodás és a globalizáció „csak” felerősíti a meglévő társadalmi-területi különbségeket és újakat hoz létre. A szabad piac, a munkaerő, a tőke, az áruk és a szolgáltatások szabad mozgása nem vezet a javak területileg kiegyenlítettebb eloszlásához, sokkal inkább koncentrációt, ezzel a területi különbségek növekedését eredményezi.)

A földrajzi tér minden pontja vagy téregysége mindig különböző, egyedi (eltérő domborzat, éghajlat, természeti erőforrások stb.). Minden területegység (pl. régió, lokalitás) mint összetett entitás unikális, különbözik az adottságaiban, a belső működésében és a külső kapcsolatrendszerében. A különböző helyeken más (kultúrájú, tehetségü, szorgalmú, képességü) emberek élnek, akik az adottságokat másként hasznosítják és mások lehetnek a törekvéseik, így a konkrét helyek más és más tartalommal telítődnek.

\section{Az egyenlőtlenség társadalmi jelenség}

A természeti és a társadalmi jelenségek megismerése, a megkülönböztetés, a szelekció, az osztályozás, a relációk megállapítása emberi/társadalmi tevékenység, értelemadás. Konkrét hely, terület, vagy társadalmi csoport pozicionálása (meghatározása, lehatárolása, értékelése) társadalmi tevékenység. A társadalmi-területi egyenlőtlenségek megállapításakor kulturálisan kódolt megkülönböztetésről, értéktartalmak megítéléséről van szó.

Szubjektivitás és kontextusfüggőség: Az egyenlőtlenségek nem önmagukban „rosszak”, hanem valamilyen társadalmi szempontból ítélhetjük egy részüket nemkívánatosnak. Adott időben és helyen morális és etikai alapon vagy más indíttatásból (pl. érdek, utilitarista pragmatizmus) ítélhetünk egyenlőtlenségeket rossznak és törekedhetünk a mérséklésükre. A megítélés kor- és helyfüggő. Minden koncepciónak - így bizonyos egyenlőtlenségek negatív megítélésének is - van létrehozója, terjesztője, elfogadója és ellenzője. Például a nyugati maszkulin gondolkodás ellenzői ugyanúgy sajátos nézőpontot képviselő („elfogult”, szubjektív) feminin aktorok, mint azok, akiket kritizálnak.

Relativitás: A társadalmi-területi egyenlőtlenségek viszonylagosak. Nincs objektív, eleve létező összehasonlítási alap. Egy társadalmi csoport pozíciója változhat a külső körülmények, a viszonyítási alap változásával is. A gyakorlatban legtöbbször a társadalmi csoportok vagy egyes területek (régiók, városrészek, települések stb.) egymáshoz képest határozódnak meg (lásd például az EU kedvezményezett régióinak a meghatározását), vagy önreflexió fényében értékelődnek. A nemkívánatos különbségek növekedését általában negatívan értékeljük, míg a csökkenésüket pozitívan. De például területi specializáció, a gazdasági szakosodás erősödésének pozitív (gazdaságilag hatékonyabb, versenyképesebb) és negatív (monocentrikus gazdaság sérülékenysége) hatásai is lehetnek. 


\section{A társadalmi és a téri mindenben egyszerre van jelen}

Minden téri módon létezik és az általunk ismert (tudott) terek a társadalom működése során konstruálódnak. A területi egyenlőtlenségek egyben társadalmi egyenlőtlenségek is, és fordítva. A társadalmi és a fizikai tér kölcsönösen konstituálják egymást (Pierre Bourdieu, Martina Löw, Doreen Massey stb.). A különbözőségek és hasonlóságok megállapítása, a relációk feltárása (struktúra) egyben a téri megjelenés, a területiség feltárását is jelenti. A tereket alkotó anyagi és társadalmi javak közötti kapcsolatok, relációk megmutatják a társadalmi különbségeket, egyenlőtlenségeket is. A tér maga a társadalom (Manuel Castells), a tér a társadalom speciális formája (Martina Löw).

Az egyének, a különféle társadalmi csoportok nemcsak önmagukban, saját attribútumaik, értékeik alapján minősülnek, hanem a külső kapcsolatrendszerük (hálózatokban elfoglalt helyük) alapján is, amit a területi elhelyezkedésük, a lakóhelyük jelenít meg. Ha ugyanaz a képességü, foglalkozású, jövedelmű stb. személy Budapesten a Rózsadombon él, annak más a társadalmi státusza, mint az ugyanazokkal a paraméterekkel rendelkező budapesti VIII. kerületben vagy egy ormánsági faluban élőnek. A magasabb presztízsű helyekhez általában magasabb szintű fizikai környezet és magasabb státuszú szimbolikus javak tartoznak. A valahová tartozás előnyökkel és hátrányokkal jár („klubhatás”).

\section{Centrum-periféria viszony}

A társadalmi-gazdasági előnyök és hátrányok halmozódnak, így különböző szintű centrumok és perifériák alakulnak ki. A centrum és a periféria kölcsönösen feltételezik egymást, közöttük kölcsönös függés, funkciómegosztás van. A centrumhoz tartozó periféria az egyik forrása a központ további fejlődésének, és a periféria kiszolgáltatott a centrumának. A centrum-periféria viszony alapvetően hatalmi különbségekre utal, a centrumrégiók tartósan befolyásuk, ellenőrzésük alatt tartják a periferikusakat (Anthony Giddens). Ennek sajátos esete az urbánus és a rurális terek kapcsolata (Gunnar Myrdal). A centrum-periféria összetartozó egység, önfenntartó rendszer csak igen lassan, történelmi léptékekben és jelentős sokkhatásra változik. Hierarchikus függőségi viszony (kizsákmányolás, kolonizáció) és aszimmetrikus erőforrás-áramlások biztosítják a fennmaradását (Immanuel Wallerstein). A centrum fejlődése autonóm és innovatív, a perifériáé a centrumtól függő és követő jellegü. (Ha jól megy NyugatEurópa gazdaságának, akkor jobbak Közép-Kelet-Európa esélyei is.) A centrumok nem a perifériáik felzárkóztatásában, új vetélytársak teremtésében érdekeltek, hanem a pozíciójuk megtartásában, a saját versenyképességük javításában (lásd a jelenlegi EU-politikát). A perifériáknak harcolniuk kell a pozíciójuk javítása érdekében. 
A társadalmi-gazdasági centrumok és a perifériák földrajzilag is elkülönülnek. A világ két részre szakadt, a globalizált termelésbe és kereskedelembe integrálódott fejlett területek hálózatára és azzal csak egyoldalú kapcsolatban álló vagy érintetlenül hagyott perifériákra. Az EU-ban centrum a „pentagon” térsége és periféria az elmaradott régiókból álló „vörös sarló”, amelynek jelentős részét a posztszocialista országok alkotják. Az országok, a régiók vagy települések központi vagy periferikus helyzete attól függ, hogy milyen erőforrások felett diszponálnak és ezzel milyen helyet foglalnak el a hatalmi térben, milyen mértékben tudnak a befolyásuk alatt tartani más területeket.

\section{Hierarchia mint egyenlőtlenség}

A világ az egymással kapcsolatban lévő, egymásra épülő különböző elemek, részrendszerek kölcsönhatásában működik. A hierarchia, a különböző területi szintek nem a fizikai valóságban léteznek, hanem az emberi gondolkodás különbözteti meg és rendezi el az egymás mellett létező elemeket és kapcsolataikat (sík ontológia, Manuel Dalanda, Bruno Latour). Az emberek a mindenkori megközelítésüknek (elvek, szabályok, fogalmak, szándékok) és eszközeiknek megfelelő rendet visznek a sokféleségbe és annak tudatában cselekszenek. Az elemek, a részek fölött álló nagyobb egységek, más szintek csak különböző relációkat, más típusú kölcsönhatásokat és más folyamatokat jelentenek, más funkciókat látnak el. A hierarchia társadalmi kategória, a társadalom működési módja, struktúrája.

Az ember számára a mindennapi világ, az azt megjelenítő tér nem egyenértékű elemek hálózata, nem neutrális kitöltött helyekből és be nem töltött űrből áll, hanem különböző mennyiségű és minőségű, eltérő jelentésű és funkciójú dolgokból és eseményekből, és ezek között eltérő intenzitású és jellegű kapcsolatok vannak. A különféle megfontolásokból (funkcionalitás, adminisztratív irányítás, hatalomgyakorlás stb.) hierarchikusan elrendezett struktúra jóformán minden ismert komplex rendszer közös vonása. A hálózatok majdnem mindig hierarchikus szintekből állnak, vagy idővel a működésük során azzá válnak. A hierarchia egyenlőtlen eloszlást, vertikális kapcsolatokat, munkamegosztást, funkciómegosztást (struktúrát) takar. A hierarchikus jelzőt legtöbbször negatív összefüggésben használjuk, pedig a hierarchikusan strukturált rendszereket a stabilitás, a gyorsaság és a jó irányíthatóság is jellemzi (Herbert Simon).

A liberális demokrácia fetisizálásáról elhíresült Francis Fukuyama szerint a társadalomban is létezik „természetes hierarchia”. Magától értetődo” mindenki számára, hogy az idegsebész státusza magasabb a társadalmi hierarchiában, mint a portásé, más a rangja a kórházban és más a társadalmi elismertsége is. Más a funkciója, más képességekkel/adottságokkal bír, és el is várjuk tőle, hogy ennek megfelelően teljesítsen, a felhalmozott személyes tőkéjét hasznosítsa. Az 
egyes területeknek, az ott élőknek is más és más az adottságuk, a társadalmi munkamegosztásban betöltött szerepük és a place-based szemléletben elsősorban azt várjuk el tőlük, hogy területi tőkéjüket minél jobban hasznosítsák.

A társadalmi esélyegyenlőséget is tükröző településhierarchia sem valamiféle külső ténybőll, adottságból, hanem a társadalom (az intézmények) működéséből ered. Az értékítéleteket is tükröző besorolások folyamatosan változó társadalmi-politikai konstrukciók. A területi szintek (skála) és rangsorok meghatározása a gyakorlati tapasztalat és az ideológia fúziója, olyan absztrakt konstrukció (metaforikus kép), amely a társadalmi folyamatokat valamilyen területi léptékbe rendezi, és ez politikai-hatalmi erőként is müködik.

\section{A nemkívánatos egyenlőtlenségek mérséklése}

A társadalmi-területi egyenlőtlenségek a társadalmi cselekvések útján termelődnek újjá, így társadalmi beavatkozásokkal akár meg is változtathatóak. A marxista gyökerü kritikai gondolkodás központi kérdése a kizsákmányolás és az abból eredő társadalmi egyenlőtlenségek mérséklése. A kapitalista termelési mód megjelenik a különféle területi struktúrákban, a materiális valóságban (pl. munkamegosztás, városi gettók), ami hozzájárul a termelési viszonyok, a társadalmi egyenlőtlenségek újratermelődéséhez is. A konkrét társadalmi-gazdasági viszonyok, a konkrét terek megélése egyben forrása is a megváltoztatására irányuló törekvéseknek.

A hátrányos területi egyenlőtlenségek mérséklése a társadalmi-gazdasági integráció előfeltétele, amely elősegíti a kevésbé fejlett területek forrásainak a minél jobb kihasználását (új források), ezáltal minden szinten erősíti a növekedését, és javít a szegényebbek (abszolút) helyzetén, amennyiben a növekedésből eredő magasabb jövedelem „helyben” marad.

\section{Társadalmi-területi szegregáció}

Az egyenlőtlenségek felszámolása nem a természeti, a kulturális, az etnikai, a nemi stb. különbözőségek mérséklésére irányul, hanem az ezekből eredő hátrányok csökkentésére, az egyenlő bánásmód, az esélyegyenlőség és a hozzáférés biztosítására.

A szegregációt szinte mindig negatív fogalomként értelmezzük. Közismert, hogy a fizikai térben megjelenő különbségek, a területi elkülönülés újratermelik a társadalmi egyenlőtlenségeket. Ugyanakkor az azonos kultúrájú, habitusú, státuszú emberek egymás közelségében érzik jól (otthonosan) magukat, míg a nagyon különböző beállítottságú, kultúrájú emberek között gyakoribbak a 
konfliktusok. Ezért a hasonló életvitelű emberek - ha tehetik - egymás közelébe költöznek. Az ilyen, saját akaratból bekövetkező társadalmi-területi szegregációt nem ítélhetjük negatívnak még akkor sem, ha ez felgyorsítja bizonyos területek gettósodását. A hasonló életstílusú emberek területi szegregációjának előnyei is lehetnek. Hasonlóak a problémáik és a közös megoldásokban érdekeltek, közös célok érdekében mozgósíthatóak.

A társadalompolitikai, a szociálpolitikai antiszegregációs gyakorlat arra a koncepcióra épül, hogy a hátrányos helyzetű emberek át-, széttelepítése (elköltöztetése), vagy a fizikai környezet megváltoztatása megváltoztatja az emberek habitusát és társadalmi változásokat indukál, ami meg fogja változtatni a térhasználatukat is (körkörös dialektikus folyamat). Az erre épülő támogatási, fejlesztési projektek csak részben jártak sikerrel, illetve gyakran nem voltak fenntarthatóak. Általában nem voltak sikeresek azok az integrációs projektek, amelyek egymástól távol álló habitusú embereket területileg integráltak. A fizikai környezet megváltoztatása a társadalmi integráció nélkül ugyancsak kudarcba fulladt.

A jelenlegi migrációs hullám a szegregáció és integráció kérdéskörét is új megvilágításba helyezi. Az egyre erősödő asszimilációs elvárások ellentétesek a „fejlett nyugati világban” megszokott kisebbségi politikával, a vallási toleranciával, a sokféleség elfogadását, a multikulturalitás előnyeit hirdető politikával, de ma már az adott helyen élő társadalmak is védelemre szorulhatnak. A status quo nem jogosít fel senkit arra, hogy bizonyos területeket, városokat, városrészeket a jövőben is birtokoljon, de történelmi tapasztalatok önvédelemre késztethetik őket. Francia, német, holland stb. példák azt mutatják, hogy a bevándorlók éppen úgy meg akarják őrizni a saját kultúrájukat (vallásukat, szokásaikat), mint a befogadó nemzet. Erdély nem Trianonnal veszett el a magyarok számára, hanem amikor a románok bevándorlása kapcsán a 18. században kisebbségbe kerültek. A székely közösség úgy volt képes fennmaradni, hogy megőrizte zártságát, integritását. (A természetvédelemben általánosan elfogadott alapelv, normatív elvárás, hogyha az újonnan elterjedő vagy korábban meggondolatlanul betelepített állatok vagy növények veszélyeztetik az őshonos fajtákat, akkor azok további térnyerését mérsékelni próbálják.) A jövőben fontos társadalmi beavatkozási terület nem a különböző szegregációk felszámolása lesz, hanem a közöttük lévő konfliktusok kezelése.

\section{Köszönetnyilvánítás}

Készült a Nemzeti Kutatási, Fejlesztési és Innovációs Hivatal - NKFIH K 115870 szerződésszámú kutatás támogatásával. 
5 